\title{
E-BRIEF
}

July 13,2017

\section{Table Stakes: Congress Will Be Sitting across from Canada at the NAFTA 2.0 Negotiations}

by

Christopher Sands

- The US Congress has redefined the US negotiating process, giving itself a larger role than it had when the Canada US Free Agreement (CUFTA) and the first North American Free Trade Agreement (NAFTA) were negotiated.

- During the negotiations that led up to CUFTA and NAFTA 1.0, Canadians could focus on the US Trade Representative (USTR) and pay less attention to Congress because it was not privy to the details of what was being negotiated until after a deal was completed. Now, as US interests press Congress to weigh in on their behalf during NAFTA 2.0 talks, they will have the means, motive and opportunity to do so. Members and Senators will voice concerns and threaten Canadian interests, and Canadian negotiators will not be able to ignore Capitol Hill safely.

"That's a good idea, but it's impossible. You'd have to reopen NAFTA and the US will never do that." Trade policy watchers (including this author) have been saying this for years, but after the 2016 election when the successful candidate, and now President, Donald Trump campaigned on making a better NAFTA deal or walking away from the agreement entirely, the impossible has become reality. On May 18, 2017 US Trade Representative Robert Lighthizer sent the required 90-day notice to Congress of the Trump administration's intent to renegotiate NAFTA. On July 17, Lighthizer is expected to publish the US negotiating objectives for NAFTA 2.0 thirty days before the negotiations can begin on August 17.

The author thanks Daniel Schwanen, John Curtis, Gilles Gauthier, Lawrence Herman and anonymous reviewers for comments on an earlier draft. The author retains responsibility for any errors and the views expressed here. 
These deadlines are dictated by the provisions of the Bipartisan Congressional Trade Priorities and Accountability Act of 2015 (TPA-2015), which granted "fast track" trade negotiation authority to the Barack Obama administration that expires on July 1, 2018. The Trump administration can request one three-year extension of negotiating authority that would then cover any agreement concluded before July 1,2021 . It is reasonable to assume that the current effort to renegotiate NAFTA will conclude by this date.

\section{Evolving American Trade Policy: Who is in Charge?}

Article I, Section 8 of the United States Constitution grants the Congress sole power to "lay and collect duties" and "regulate commerce with foreign nations." For most of US history, the Congress sought to protect and promote US economic interests until the Great Depression followed the Smoot-Hawley Tariff Act of 1930 and led congressional leaders to shift in favor of reciprocal tariff reductions to be negotiated by the executive branch, typically with the Secretary of State taking the lead role.

As I.M. Destler noted in his history of U.S. Trade policy:

From the Reciprocal Trade Agreements Act of 1934 through the Trade Expansion Act of 1962, the means by which Congress delegated authority for trade negotiations remained basically the same. Successive statutes authorized executive branch officials to negotiate (within specifed numerical limits) reductions in U.S. tariffs, in exchange for reductions by U.S. trading partners. When a deal was finally struck, it could be implemented by presidential proclamation, without further recourse to Capitol Hill." Destler (2005, p.71).

President John F. Kennedy accepted a recommendation from the Senate Finance Committee to establish a Special Trade Representative to lead US trade negotiations from the White House, rather than the State Department. As foreign nontariff barriers became an important part of the US negotiating agenda, Congress began seeking to make amendments to trade agreements where the gains were not seen to be reciprocal, setting up a situation in which US trade partners had to negotiate with the executive branch only to face a second round of negotiations with the Congress to get a deal ratified. The Ford administration negotiated a fix for this in the Trade Act of 1974, which established the "fast track" process that gave agreements negotiated by the executive branch an upor-down vote in Congress with no amendments.

As Canadians saw with NAFTA 1.0 in 1993, congressional ratification (and passage of any necessary implementing legislation) was not a foregone conclusion. However, the structure of the US trade negotiating team was stable and clear: new agreements were negotiated by the United States Trade Representative, who headed a team that was part of the Executive Office of the President and reported regularly to the Congress, in particular to the House Ways and Means Committee and the Senate Finance Committee. For trade disputes, the US Department of Commerce was authorized to handle trade enforcement, including investigations of unfair foreign trade practices and litigation through dispute resolution panels convened under NAFTA or WTO authority. Congress paid attention, but took a backseat to the executive branch on trade most of the time.

Accordingly, our attention has been focused on Trump and his trade team, including Lighthizer and US Secretary of Commerce Wilbur Ross. Yet the US strategy in NAFTA renegotiation talks will be shaped by the Congress to an extent not seen since the Ford administration. Before the 2016 election in which both leading candidates for president rejected the Trans-Pacific Partnership, the Congress had already moved to assert its constitutional authority over trade. 


\section{Congress Asserts its Authority over Trade}

TPA-2015 was intended to cover the negotiation of the Trans-Pacific Partnership and the Transatlantic Trade and Investment Partnership, and Congress made its grant of authority conditional. First, as with the most recent previous TPA legislation in 2002, Congress takes responsibility for setting trade negotiating objectives in three categories: overall objectives, principal objectives, and other priorities. TPA-2015 built in unprecedented notification and consultation requirements to allow House and Senate members to monitor talks and provide input throughout.

TPA-2015 also established an Advisory Group on Negotiations in both the House and the Senate and required that the executive branch brief and consult with both before, during and after any trade negotiations. Any member of the House or Senate may join these advisory committees.

This marks a change. The US Trade Representative (USTR) has routinely consulted with Congress on trade negotiations through the House and Senate leadership (both parties) as well as the House Ways and Means Committee and the Senate Finance Committee, in addition to consultations with a number of other House and Senate committees, seven others from each house to be precise. ${ }^{1}$ However, under TPA-2015, Lighthizer must brief more members, and provide more access to information about the negotiations as they proceed. Leaks of sensitive information, long part of international trade negotiation, will be inevitable with information so widely shared. During the negotiations that led up to CUFTA and NAFTA 1.0, Canadians could focus on USTR and pay less attention to Congress because it was not privy to the details of what was being negotiated until after a deal was completed. Now, as US interests press Congress to weigh in on their behalf during NAFTA 2.0 talks, they will have the means, motive and opportunity to do so. Members and Senators will voice concerns and threaten Canadian interests, and Canadian negotiators will not be able to ignore Capitol Hill safely.

The influence that Congress will have on USTR through consultations during the NAFTA renegotiations may be enhanced by the fact that one-third of the 168 House and Senate members who are currently in leadership positions (including committee chairs and ranking members) were on Capitol Hill in elected or senior staff positions for the ratification of the Canada-US Free Trade Agreement (CUFTA) or the NAFTA itself. Fifteen of the sixteen who were eligible to vote on CUFTA voted in favor, but less than half of those who voted on NAFTA ratification (15 of 33) voted in favor. Narrowing the list to only the House Speaker and Minority Leader, the Senate Majority and Minority leaders, and the chairpersons and ranking members of the sixteen House and Senate committees regularly consulted by USTR, 60 percent voted on CUFTA or NAFTA ratification. Of these veterans, all voted in favor of CUFTA (12 of 12) and less than half voted to approve NAFTA (12 of 33).

\section{Congress Sets the Pace}

Another consequence of the language of TPA-2015 is that a timetable for the NAFTA renegotiation is established for negotiation, consideration and ratification. The Trump administration has to complete each step within the allotted time in order to receive expedited review and a vote on the agreement and implementing legislation.

1 In addition to the House Ways and Means Committee and Senate Finance Committee, USTR regularly consults with the House committees on Appropriations, Agriculture, Energy and Commerce, Financial Services, Foreign Affairs, Judiciary, and Small Business as well as the Senate committees on Appropriations, Agriculture Nutrition and Forestry,

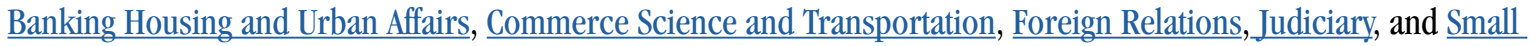
Business and Entrepreneurship. That is a total of eight committees in each chamber, sixteen total. But any member of the House or Senate not on one of these committees can join an Advisory Group on Negotiations under the terms of TPA-2015, so no one in Congress who wants to receive a briefing is excluded. 
Canadians and Mexicans will also benefit from the transparency of this structured approach, as well as from the public disclosure of texts to the US Congress and public, since these documents will be available to them as well.

Under TPA-2015, the first phase of NAFTA renegotiation begins with the written notification to Congress of the intent to enter into negotiations, which occurred on May 18, 2017. Thirty days before the renegotiation begins, USTR will publish on its website the specific United States negotiating objectives along with a description of how a new agreement would address these objectives and benefit the United States. The May 18 notification places the likely date of the publication of US negotiating objectives on July 17, and the earliest possible start date for the negotiations on August 16; a delay in the publication of the US objectives would delay the start of the negotiations accordingly.

During the negotiations, USTR is obligated to consult with all eight House and eight Senate committees and respond to requests for information from the House and Senate Advisory Groups on Negotiations. Then, 180 days prior to the conclusion of the negotiations, USTR must submit a report to the House Ways and Means and Senate Finance committees on any potential changes to US trade remedy legislation that may be required. Notification of Congress of the Trump administration's intent to enter into a new agreement is required 90 days prior to the conclusion of a final agreement, as well as a detailed report to the US International Trade Commission (USITC) for its assessment of the likely impact of the agreement. Sixty days prior to signing a final agreement, TPA-2015 obligates USTR to publish the text of the final agreement on its website.

Once an agreement with Canada and/or Mexico is signed, the review phase of the negotiation begins. Within 60 days of the signing, USTR must submit to Congress a description of any changes that the agreement would require to US law. The USITC must complete its assessment of the agreement's potential impact within 105 days of the signing of the agreement. Sometime after this, TPA-2015 requires that the Trump administration submit to Congress a copy of the final legal text of the agreement along with environmental and labour impact assessments and a plan for implementation and enforcement of the agreement. Then the administration must provide a draft of necessary implementing legislation no less than 30 days after that.

The final phase of the process established by TPA-2015 is Congress' debate and votes on the agreement and associated implementing legislation. If the Trump administration has met all of the requirements of TPA-2015, Congress has given itself 90 session days to complete the process.

If Canada, Mexico and the United States reach an agreement on a NAFTA 2.0 text that complies with the terms and conditions set out in TPA-2015, Congress will give the final agreement and associated implementing legislation expedited consideration, a guaranteed up-or-down vote without the possibility of amendment. This timetable would also apply to any bilateral trade agreement that might emerge for certain issues separated from, or in place of, a trilateral agreement.

\section{What having the US Congress at the Table Means for Canada}

The US TPA-2015 legislation provides some clarity on what to expect in the months ahead, as well as some of the constraints on the US negotiators. The importance of Congress in this process was confirmed by the attention to congressional priorities in the 2017 Trade Policy Agenda issued in January, and the draft notification to Congress on NAFTA Renegotiation that was leaked in March. There are some important implications of this shift in the US negotiating process for Canadians.

The Trudeau government and the Canadian public will have unprecedented access to detailed information on NAFTA renegotiation. This is thanks to the TPA-2015 requirements for public notice and consultation, publication of negotiating objectives, draft and final texts of the agreement. TPA-2015 also stipulates that the administration 
submit environmental and labour market impact assessments and a plan for implementation and enforcement, and publish draft implementing legislation, before Congress will begin the ratification process. Contrast this with the Canada-EU Comprehensive Economic and Trade Agreement (CETA), for which a text was not available for months after signing.

Completing all TPA-2015's required steps for NAFTA renegotiation will almost certainly inject all of this information into one or more elections, assuming that the renegotiated agreement will require changes to US legislation to be implemented. Statutory deadlines added up mean that the US Congress is very unlikely to begin debate over ratification and implementing legislation before the July 1, 2018 date for Mexican presidential and congressional elections. And it is unlikely that the Congress will take up this legislation before the November 6 , 2018 US midterm elections. Assuming that neither of these elections makes concluding an agreement on NAFTA 2.0 impossible, it may be that the next Canadian federal election will determine the fate of the agreement as the United States turns, shortly after the 2018 midterms, to focus on the 2020 US presidential and congressional elections. ${ }^{2}$

Social media in all three countries will resound with analysis and debate of details revealed in the United States as a result of the TPA-2015 process. And unlike the CETA or TPP debates, or even the original NAFTA and CUFTA debates, the public will not be considering a mere change to trade rules from a standstill position. NAFTA renegotiation may alter the rules by which firms continue to invest, hire and plan the integration of their supply chains continentally. It is akin to making repairs to a car while driving it.

With the public paying close attention, the transparency required by TPA-2015 could help reassure voters. But Congress may discover that it makes an agreement with the United States impossible. The US side of the negotiating table will include the USTR team and as many as 535 congressional sidekicks. The only other time that TPA-2015 was used, for the TPP negotiations, congressional interest was muted by the fact that the negotiation was for something new and, in a sense, hypothetical. As with repealing and replacing the Obamacare legislation, the fact that changes are being made to rules that people are relying on today might make it hard to come to an agreement on changing NAFTA, however much it might need improvement.

\section{New Rules for Trade Negotiation, but Rules}

The first reaction after realizing that something you thought was impossible has just happened is to think that anything is now possible. The US Congress effort to keep the Obama administration on a short leash on trade, and the Trump administration's decision not to seek a new grant of trade promotion authority for NAFTA

2 However, the rules do make the conclusion of a NAFTA 2.0 agreement by January 2018 theoretically possible. Suppose talks start on August 17, 2017 and conclude after one month (possible if only modest changes to the existing agreement are involved, or if the previously negotiated terms of the TPP agreed to by all three NAFTA countries are the basis for a new text). On September 17, USTR gives Congress 90 days' notice of the intent to conclude an agreement and provides essential details to the US International Trade Commission for its review. On December 16 the 90 day period would be up, and USTR could submit a draft text, draft implementing legislation, environmental and labour market impact assessments, and implementation and enforcement plans. 30 days later, and no sooner, Congress could begin its deliberations over the implementing legislation, most likely on January 16 due to the federal holiday on Martin Luther King Jr. Day January 15. Allowing each chamber two session days for debate, President Trump could have the legislation on his desk on January 20. Yet this timetable is extremely unlikely given the understaffing of the Trump administration which will make it difficult to deliver reviews and draft legislation this quickly. It seems more likely that, as US Secretary of Commerce Wilbur Ross told Bloomberg News in March, talks will begin at the end of 2017 (August would qualify) and would take about a year. This could result in legislation on the president's desk in January 2019. 
renegotiation - which it might have envisaged in order to seek a less restrictive set of rules - has complicated but also clarified the path forward to NAFTA 2.0.

The $115^{\text {th }}$ Congress that was elected with Donald Trump in 2016 has made extensive use of another piece of legislation passed in the 1990s, The Congressional Review Act of 1996, to strike down agency regulations for exceeding congressional intent as indicated in legislation. It can be inferred from this that the present Congress at least is unlikely to permit NAFTA 2.0 to take effect without its express consent.

That's why Trump's trade team has met every deadline in TPA-2015 so far, and Canadian negotiators can rely on this legislation for a roadmap to drive NAFTA 2.0 through the US political process. 


\section{References}

Destler, I.M. 2005. American Trade Politics Fourth Edition. Washington: Institute for International Economics.

\section{Legislation:}

Bipartisan Congressional Trade Priorities and Accountability Act of 2015.

Congressional Review Act of 1996.

Smoot-Hawley Tariff of Act of 1930.

Trade Act of 1974.

This E-Brief is a publication of the C.D. Howe Institute.

Christopher Sands is senior research professor and director of the Center for Canadian Studies at the Johns Hopkins University School of Advanced International Studies (SAIS) and a nonresident senior associate of the Center for Strategic and International Studies (CSIS) in Washington, D.C.

This E-Brief is available at www.cdhowe.org.

Permission is granted to reprint this text if the content is not altered and proper attribution is provided. 